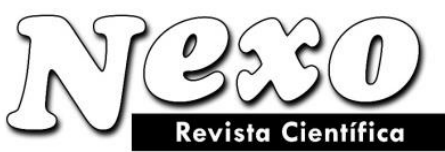

Vol. 34, No. 01, pp. 457-468/Marzo 2021

\title{
Modeling an enterprise's operations based on marginal ideology
}

\section{Modelando las operaciones de una empresa basadas en la ideología marginal}

\author{
Mikhail Samuilovich Gasparian*, Irina Anatolievna Kiseleva, Valery Aleksandrovich Titov, \\ Natalia Alekseevna Sadovnikova \\ Plekhanov Russian University of Economics, Moscow, Russia. \\ *mikhail_gasparian@mail.ru
}

(recibido/received: 21-November-2020; aceptado/accepted: 07-January-2021)

\begin{abstract}
The paper explores the topical subject of modeling enterprise operations with the use of marginal analysis. The market economy is characterised by the heightened instability of the complex socioeconomic system, which is almost impossible to fully grasp and study. Businesses face intense competition. Adequate managerial decision-making requires in-depth comprehensive assessments of the situation and reliable forecasting. A firm that makes correct forecasts gains additional profit compared to one abstaining from forecasting. Meanwhile, a firm making an incorrect forecast loses most of all. Managerial decisions often rely on break-even analysis, i. e., marginal analysis. This paper explores examples where even in cases when disadvantageous choices are made (as shown by break-even analysis), the setting can still lead to positive results, i. e., at least a moderate profit, through the validation of the managerial decision by further analysis and calculations. The methods of enquiry, retrospective and document analysis, as well as synthesis, generalisation and systematisation were used.
\end{abstract}

Keywords: enterprise, marginal analysis, managerial decisions, model.

\section{RESUMEN}

El artículo explora el tema de actualidad del modelado de operaciones empresariales con el uso del análisis marginal. La economía de mercado se caracteriza por la mayor inestabilidad del complejo sistema socioeconómico, que es casi imposible de comprender y estudiar por completo. Las empresas se enfrentan a una intensa competencia. Una adecuada toma de decisiones de gestión requiere evaluaciones exhaustivas en profundidad de la situación y pronósticos fiables. Una empresa que hace pronósticos correctos obtiene ganancias adicionales en comparación con una que se abstiene de pronosticar. Mientras tanto, una empresa que hace un pronóstico incorrecto es la que más pierde. Las decisiones gerenciales a menudo se basan en un análisis de equilibrio, i. e., análisis marginal. Este documento explora ejemplos en los que, incluso en los casos en que se toman decisiones desventajosas (como se muestra en el análisis de equilibrio), el entorno puede conducir a resultados positivos, i. e., al menos una ganancia moderada, a través de la validación de la decisión gerencial mediante análisis y cálculos adicionales. Se utilizaron los métodos de indagación, análisis retrospectivo y documental, así como síntesis, generalización y sistematización.

Palabras clave: empresa, análisis marginal, decisiones gerenciales, modelo. 


\section{INTRODUCTION}

In each organisation, there is a person in charge of managerial decision-making informed by various kinds of analysis. The manager uses this analysis to gain an understanding of financial results and then makes crucial decisions. Such decisions shape the company's success and global attractiveness. Each of the manager's decisions influences the organisation's prices, costs and output.

The most common approach to regulate costs (and output/sales) is via determining the break-even point. It marks the moment when all costs of the organisation are fully covered by revenues. In calculating the break-even point, many managers rely on marginal analysis.

Marginal analysis is the most common and one of the most efficient types of analysis, as it provides visibility into the ratios of fixed and variable costs and helps to mitigate risks and calculate the proportion between price and sales volumes. Most companies use marginal analysis to gain more in-depth insight into operations and financial performance. Experts can deliver precise results and proposals on how to optimise and improve company operations.

\section{BASIC THEORY OF MARGINAL ANALYSIS}

Managerial decisions often rely on break-even analysis, also referred to as marginal analysis. Its principal reference is the composition of costs, sales and profit (Makarenko, 2020; Tereshchenko, 2019; Domashchenko, 2010).

Marginal analysis is used in the developed market economy settings as a tool:

- to determine the level of sales required to generate profit;

- to determine the break-even point where the organisation's losses are covered;

- to measure the influence of different factors on profit to effectively manage profit forecasting;

- to attain optimal managerial decision-making.

To begin with, marginal analysis requires an analysis of costs. They should be classified as fixed and variable costs. Consider a classification of costs in an organisation (Figure 1).

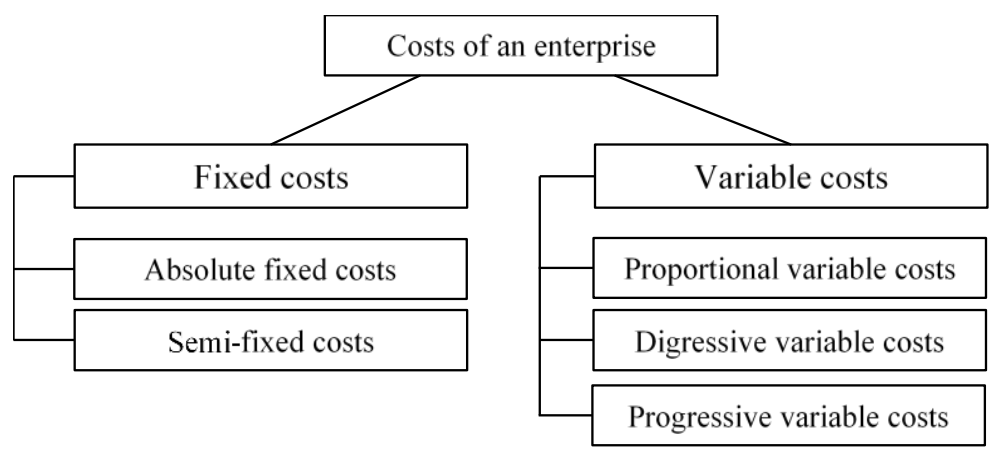

Figure 1. Classification of costs in an organisation

Variable costs always change with the level of output and/or sales. The degree of this dependence varies. In the case of a proportional relation, the total of variable costs for specific product types rises or declines with the rise or decline of sales (output). A good example is a natural loss of materials or commodities. 
In a digressive pattern, the total of variable costs for specific product types rises slower than sales (output). A good example is advertising spending in case of strong performance.

In a progressive pattern, the total of variable costs for specific product types rises faster than sales (output). A good example is a payroll in sales (in a hybrid, fixed plus performance-linked remuneration scheme) (Bardovskii, 2019; Zhilkina, 2020; Vakhitov, 2018; Shapkin, 2013).

Fixed costs never change with the level of output and/or sales. This type of cost is even borne by organisations when they temporarily suspend operations.

Absolute fixed costs include primarily rental spending on commercial and production space.

Semi-fixed costs include spending on low-cost expandable assets.

All fixed costs should be analysed only in the short run of business operations.

\section{METHOD OF MARGINAL ANALYSIS BREAK-EVEN POINT CALCULATIONS}

The marginal analysis relies on certain indicators to be used in calculations (Gomola, Kirillov, 2019; Kerimov, 2020).

Principal indicators:

- VC: Variable costs;

- FC: Fixed costs;

- MR: Marginal revenue;

- Q: Output in physical terms (product quantity);

- $Q_{i}^{b} Q_{i}^{b}$ : Break-even point (critical level of output in physical terms).

Marginal revenue (or contribution margin) is the total of fixed costs and profit for the period. This measure shows, first, the organisation's revenue contribution to cover spending and other costs crucial for ongoing operations, and then the remaining revenue after all fixed costs are covered, which constitutes the profit or loss.

Consider the main approaches to calculating the break-even point, including analytical and graphical methods and calculation of unit gross margin (Filippova, 2019; Cheredanova, 2018; Bezuglaia, 2013; Kosov et al., 2016).

Under the analytical (algebraic) method, sales revenue in monetary terms is determined as follows: $T R=V C+F C+P_{r}$, where:

TR is total revenue in monetary terms;

$P_{r} P_{r}$ is profit in monetary terms. 
To calculate the break-even point in monetary terms, the following transformations are made: $T R=p \times Q$, where $p$ is the average unit price in monetary terms.

Next, variable costs are represented as follows: $V C=v c \times Q$, where $v c$ is variable costs per unit expressed in monetary terms.

Use the above formulas in the principle equation as follows: $p \times Q=v c \times Q+F C+P_{r}$, it follows that: $(p \times Q)-(v c \times Q)-F C=P_{r .}$.

As we said earlier, profit at the break-even point is zero and is sufficient to cover all costs, accordingly, if we subtract variable and fixed costs from total revenue, the result should be zero. It follows that: $(p \times Q)-(v c \times Q)-F C=0$.

Transform the formula as follows:

$$
\begin{aligned}
& Q(p-v c)-F C=0 ; \\
& Q(p-v c)=F C ;
\end{aligned}
$$

Sales at the break-even point will be calculated as follows: $Q^{b}=\frac{F C}{\rho-v c}$.

Consider the graphical method of calculating the break-even point. This method provides for convenient visualisation of the relationship between the indicators and analysis, which can be also rendered in a graphical form.

Consider axes for plotting the indicators on the graph.

The first one is the horizontal axis (X). It represents the values of output (Q) in physical terms.

The second, vertical, axis (Y) represents costs (revenues) in monetary terms.

To make the chart, plot the level of fixed costs (FC) on the vertical axis. Given that these costs do not change with output, plot a line in parallel to the horizontal axis from the FC point. This is the "line of fixed costs".

To chart the line of variable costs (VC), plot several points on the chart. Set a reference point on the horizontal axis corresponding to a single unit and a reference point on the vertical axis to mark the level of variable costs per one unit. Put the main point at the intersection of the reference lines drawn from the respective points. Repeat the step for two units, three, four units and so on. Connect the resulting points with a line, which is the "line of variable costs".

To plot the line of total costs (TC), start from the beginning of the line of fixed costs on the vertical axis at the point FC and draw a line in parallel to the line of variable costs. The line representing the total of fixed and variable costs is the "line of total costs".

Next, plot the line of revenue (TR). For that, find a reference value on the horizontal axis corresponding to a single unit and mark another reference value on the vertical axis corresponding to the price of a single unit in monetary terms. Draw lines from the set points to their intersection and mark the main point. 
Repeat the step for two units, three, four units and so on. Connect the resulting points with a line, which is the "line of revenue".

To mark the break-even point, find the intersection of the "line of revenue" and the "line of total costs." Mark the break-even point by the symbol CYR. The result is shown in Figure 2.

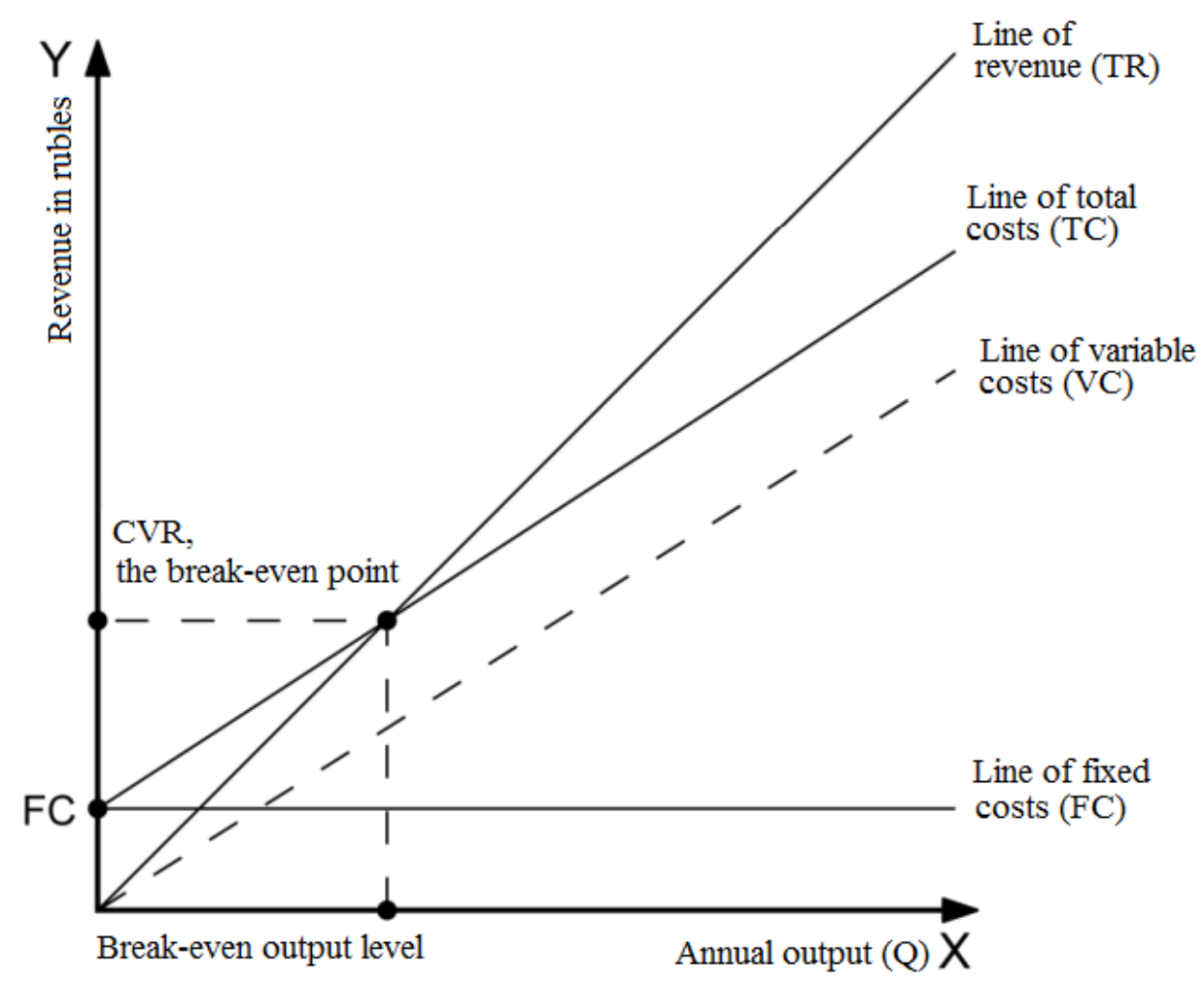

Figure 2. Break-even chart

The above model (break-even chart) is linear. It implies a perfect market and the sales curve is always linear. Total costs are only linear when the cost of labour and material resources is fixed and constant. Otherwise, where the curves are not linear, this method of analysis will only provide an approximation and the break-even point will only be a reference value.

As long as most of the time, the curves are nonlinear, multiple break-even points exist. This reflects the imperfect market settings.

In this case, the enterprise resolves to add new production capacities. As a result, variable costs are no longer in a direct proportion to sales and fixed costs start to rise. In this setting, all indicators should be represented in nonlinear forms, and this representation can be more precise than a linear representation. Consider a nonlinear break-even chart. 


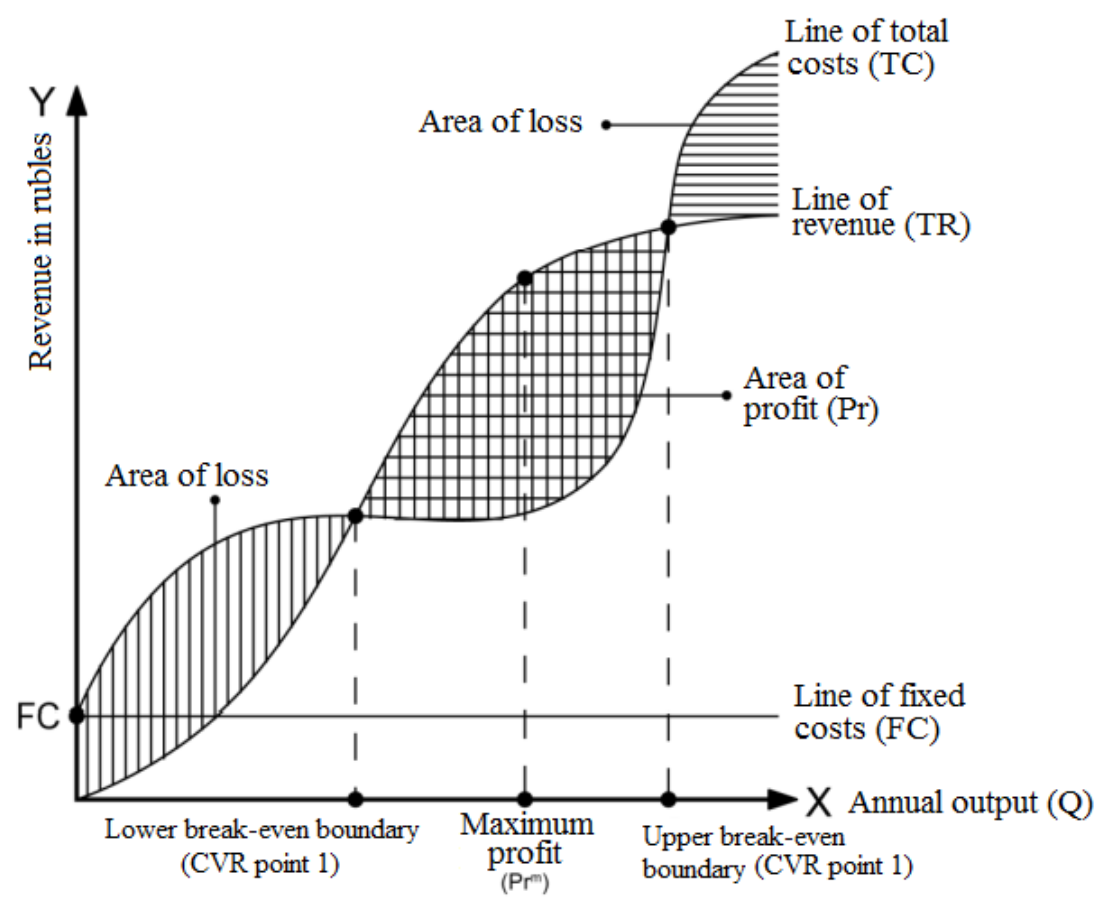

Figure 3. A nonlinear break-even chart

As can be seen from the chart, the organisation turns a profit in the interval between the lower and upper break-even boundary where the revenue curve is above the cost curve. For a more specific representation of this setting represented in the chart, add CVR points, i. e., the lower and upper break-even boundary. The area of the closest position of marginal costs and marginal revenue is marked by point $\left.{ }_{r}^{m}\right)$, the "point of maximum profit." As can be seen from the chart, the enterprise still turns a profit but it approaches the upper break-even boundary and after that starts to make losses.

This analysis indicates which product and in what amounts to produce and at what price to sell it.

Next, consider the analysis of unit gross margin (Gubanov, 2014; Foss, 2007; Kleiner, 2014).

Previous calculations used the formula $Q^{b}=\frac{F C}{\rho-v c}$, where $p-v c$ indicated the level of revenue including fixed costs and profit per unit. Put the "marginal revenue" value in the denominator and render the formula as follows: $Q^{b}=\frac{F C}{M R_{i}}$.

To find the critical level of sales and/or output at the break-even point in monetary terms, multiply either side of the equation by the average price of the product (products): $Q^{b} \times p=\frac{F C \times \rho}{M R_{i}}=\frac{F C}{\frac{M R_{i}}{P}}$.

The indicator $\frac{M R_{i}}{p}$ shows the share of marginal revenue $M R_{i}^{p}$ in the price of the product (unit), i. e., the "marginal revenue rate" $\left(n_{i}\right)$. The indicator is measured as percentage.

Example:

$$
M R_{i}^{p}=146-77=69 \text { rubles }
$$




$$
n_{i}=\frac{69}{146}=0,4726 \text { or } 47,26 \%
$$

Critical level of sales and/or output at the break-even point:

$$
\begin{gathered}
Q_{r u b}^{A}=\frac{F C}{n_{1}}=\frac{89909}{0,4726}=190243 \mathrm{rub} \\
Q_{r u b}^{A}=Q_{A}^{b} \times p_{i}=1303 \times 146=190243 \mathrm{rub}
\end{gathered}
$$

In the end, the organisation chooses its own calculation methods as may be more convenient. Many experts performing the analysis would combine two methods and render their findings more precisely on a chart. Or, they can verify the findings in additional calculations.

With a picture of the organisation's condition, the next step is to decide on financial policies (whether it is viable to produce something, what equipment should be used, etc.). All such decisions will be only made after the validation of managerial decisions.

\section{VALIDATION OF MANAGERIAL DECISIONS BY MEANS OF MARGINAL ANALYSIS}

Marginal analysis sets several questions that need to be resolved properly. Consider some of them (Kiseleva \& Simonovich, 2014a; Morrow, 2007; Khrustalev \& Slavianov, 2011; Porter, 2005).

How does one validate the manufacture vs. purchase decision? This is one of the first questions following an exercise of marginal analysis. Finding an answer to it would help to bring down costs and increase profit by making an optimal choice between purchasing some products or relying on internal production.

A clear example of the complexity of this choice can be found in the production of equipment, such as phones. Manufacturers can either produce parts on their own or purchase them from other companies.

In the case of own production, fixed costs would be 200,000 monetary units (spent on equipment per year) and variable costs per unit would be 100 monetary units. Alternatively, the same parts can be bought in the required amount at 150 monetary units each. That brings the question of which option is preferable. To address it, consider some additional calculations.

The cost of parts will be as follows in the formula: $3=\mathrm{p} \times \mathrm{x}$, where $p$ is the price per unit and $x$ is the annual requirements.

Meanwhile, production costs include variable and fixed costs. The formula is a follows: $3=a+b \times x$. Next, determine the level of output at which the cost of production and the cost of purchasing would be equal:

$$
p x=a+b \times x \rightarrow 150 p \times x=200000 p+100 p \times x=200000 p \rightarrow x=4000 \text { units }
$$

The calculation suggests that if the company needs more than 4,000 parts per year, the preferable option would be to maintain own production rather than purchase items from other manufacturers. If less than 4,000 parts are needed per year, the preferable solution would be to purchase parts instead of opting for own production. The findings are laid out in Figure 4. 


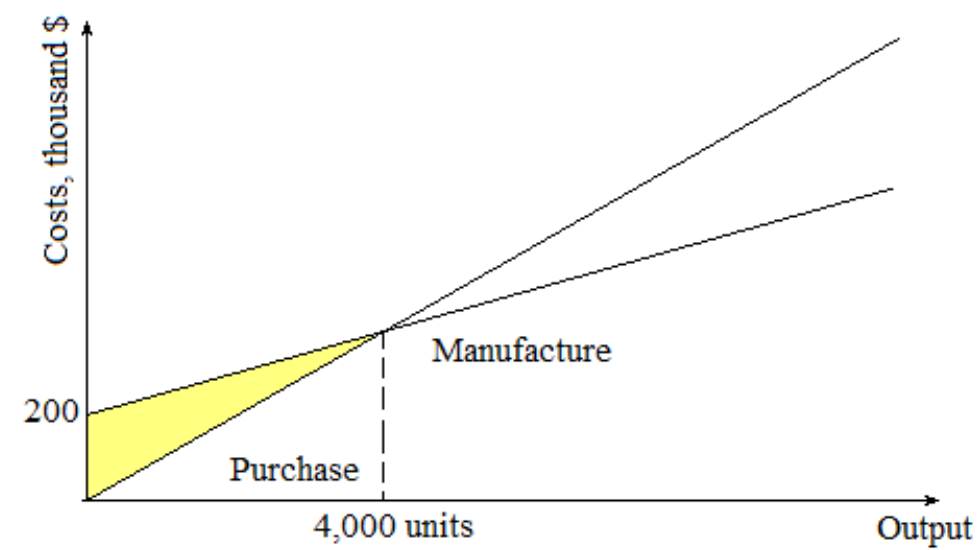

Figure 4. Validation of the "manufacture vs. purchase" decision

Most importantly, make sure to also consider other indicators affecting the decision, i. e., the enterprise capacity, job cuts or job creation, product quality, fluctuations of production levels, etc.

Next, consider an example of validating a decision on accepting an order at a price below the critical level. Such a setting occurs when there is a sharp slowdown of production or in case of failure to properly build a portfolio of orders and set up production capacities in a proper proportion.

E. g., a company operates production facilities with the potential to deliver an output of 100,000 parts, and their market price is 200 monetary units each. The enterprise's fixed costs equal 7,200,000 monetary units, while variable costs are 90 monetary units per part. Calculate the cost of a single unit (C):

$$
\begin{gathered}
\mathrm{C}=\mathrm{A} / \mathrm{VS}+\mathrm{b} \\
\mathrm{C}=7200000 / 100000+90=72+90=162
\end{gathered}
$$

Next, calculate profit $(\mathrm{P})$ :

$$
\begin{gathered}
P=V S(p-b)-A \\
P=100000(200-90)-7200000=3800
\end{gathered}
$$

The break-even level of sales is calculated as follows:

$$
\begin{gathered}
\mathrm{VScr}=\mathrm{A} /(\mathrm{p}-\mathrm{b}) \\
\mathrm{VScr}=7200000 /(200-90)=65454 \text { units } \\
\mathrm{BZ}=(\mathrm{VSact}-\mathrm{VScr}) / \mathrm{VScr} * 100 \\
\mathrm{BZ}=(100000-65454) / 100000 \times 100 \%=34,5 \%
\end{gathered}
$$

Consider a market setting in which the volume of orders placed with the company declined to 30,000 units, while the fixed and variable costs remained unchanged. Calculate the cost of a unit, as well as profit and the break-even level of sales:

$$
\mathrm{C}=\mathrm{A} / \mathrm{VS}+\mathrm{b}=7200000 / 30000+90=240+90=330
$$




$$
\begin{gathered}
\mathrm{P}=\mathrm{VS}(\mathrm{p}-\mathrm{b})-\mathrm{A}=30000(200-90)-7200000=(3900000) \\
\mathrm{VScr}=\mathrm{A} /(\mathrm{p}-\mathrm{b})=7200000 /(200-90)=65454 \text { units } \\
\mathrm{BZ}=(30000-65454) / 30000 \times 100 \%=-118,18 \%
\end{gathered}
$$

The result indicates that the enterprise has a high relative weight of fixed costs in the revenue for the period. The sharp decline in the number of orders affected the enterprise negatively.

As managers analyse the market situation and the company's position, many potential ways out would be up for them. Consider next a decision made by a manager on selling the products below the critical price level.

Say, the enterprise agreed to accept an order for 50,000 items at 180 monetary units each, while the critical price level is 182 monetary units. That said, the enterprise would have to spend 160,000 monetary units on design and technology.

Following is an analysis to validate the advantages of this method of solution:

$$
\begin{gathered}
C=(7200000+160000) /(30000+50000)+90=92+90=182 \\
P=30000(200-90)+50000(180-90)-7200000=440000 \\
\operatorname{VScr}=(7200000+160000) /[(3 / 8 \times 200+5 / 8 \times 180)-90]=7360000 /(187,5-90)=75487 \text { units }
\end{gathered}
$$

$$
\mathrm{BZ}=(80000-75487) / 80000 \times 100 \%=5,64 \%
$$

As can be seen from the calculations, even if the enterprise accepts additional orders on such seemingly disadvantageous terms, this decision will be justified. The company will be already making a profit.

Consider the final case of validation of managerial decisions concerning the choice of machines and equipment.

One of the important decisions in the optimisation of production costs is the choice of optimal machines and equipment for production (Kiseleva \& Simonovich, 2014b; Chereshkin, 2014). The importance of this choice can be illustrated with the example of three options of equipment:

Table 1. Example of the equipment options for production

\begin{tabular}{|l|l|l|c|}
\hline Option & Fixed costs & Variable costs per unit & Total costs \\
\hline A & 2000 & 2 & $C_{A}=2000+2 x$ \\
\hline B & 5000 & 1 & $C_{B}=5000+x$ \\
\hline C & 8000 & 0,5 & $C_{C}=8000+0,5 x$ \\
\hline
\end{tabular}

A manager needs to determine what production level will create the biggest advantages for using a specific type of equipment.

First, the critical output volume has to be found for two options of equipment by making an equation:

$$
C_{A}=C_{B} \rightarrow 2 x=5000+x \rightarrow(5000-2000) / 1=3000 \text { units }
$$


Next, the step is repeated with other equipment too:

$$
C_{B}=C_{C} \rightarrow 5000+x=8000+0,5 x \rightarrow 0,5 x=3000 \rightarrow x=6000 \text { units }
$$

Thy analysis suggests that if the annual output is at or below 3,000 units, the first type of equipment (A) is preferable. If the annual production volume falls between 3,000 and 6,000 items, the second option (B) will be preferable. With an annual output of above 6,000 units, the third type of equipment (C) will be preferable. The findings are laid out in Figure 5.

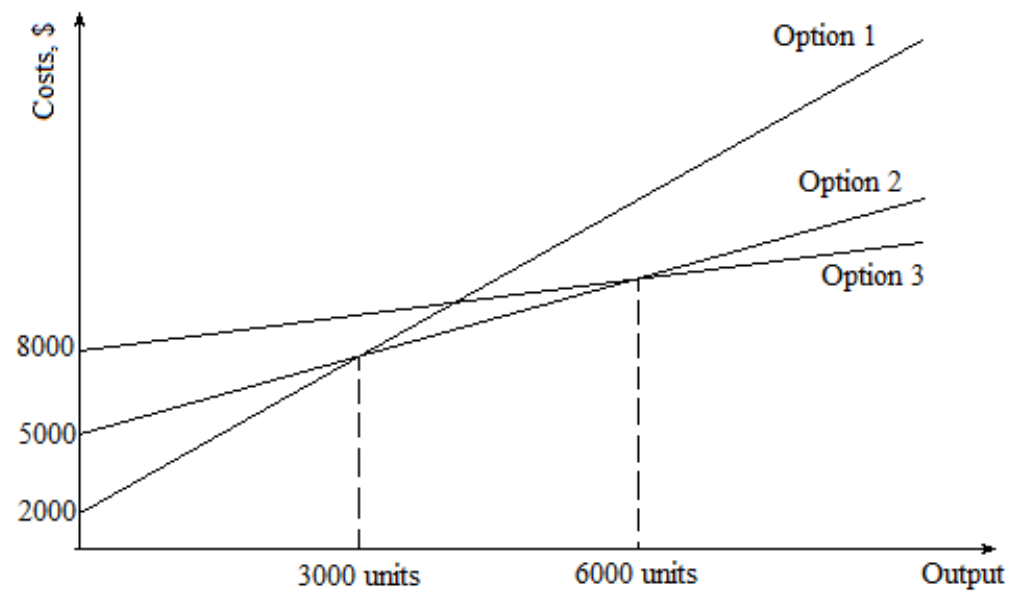

Figure 5. Equipment efficiency at the enterprise

Assume the decision was made wrong and the choice of equipment was faulty, one calculates the resulting losses for the organisation.

E. g., the level of output at the enterprise equaled 4,000 units. The third type of equipment (C) was chosen. Calculate losses using the formula as follows:

$$
(8000+0,5 \times 4000)-(5000+1 \times 4000)=12000-9000=3000 .
$$

Accordingly, the wrong choice resulted in a loss of 3,000 monetary units).

\section{CONCLUSIONES}

Marginal analysis plays an important role in managerial decision-making. It allows the enterprise to make a choice concerning the level of output, proceed with (seemingly) disadvantageous decisions, increase or decrease some measures of costs.

Additional calculations should always follow after marginal analysis for validating managerial choices.

This paper explores examples where even in cases when disadvantageous choices are made (as shown by break-even analysis), the setting can still lead to positive results, i. e., at least a moderate profit, through the validation of the managerial decision by further analysis and calculations.

Other examples concerned the idea that the choice of equipment for production is of principal importance as it allows the company to cut additional costs in production. 
An important highlight is determining the break-even point, which indicates the moment of time when all of the company's costs are fully covered by revenues. This analysis addresses the interrelations of costs, sales and profit.

\section{ACKNOWLEDGEMENTS}

This research was performed in the framework of the state task in the field of scientific activity of the Ministry of Science and Higher Education of the Russian Federation, project "Development of the methodology and a software platform for the construction of digital twins, intellectual analysis and forecast of complex economic systems", grant no. FSSW-2020-0008.

\section{REFERENCES}

Bardovskii, V. P. (2019). Ekonomika [Economics]. Moscow: INFRA-M.

Bezuglaia, N.S. (2013). Ekonomicheskaya bezopasnost predpriyatiya. Sushchnost ekonomicheskoi bezopasnosti predpriyatiya [Economic security of an enterprise. The essence of economic security of an enterprise] Rossiiskoe predprinimatelstvo [The Russian Journal of Entrepreneurship], 4(1), 63-67.

Cheredanova, L.N. (2018). Osnovy ekonomiki i predprinimatelstva [Fundamentals of economics and entrepreneurship]. Moscow: Academia.

Chereshkin, D.S. (2014) Upravlenie riskami i bezopasnostyu [Managing risks and security]. St Petersburg: Lenand.

Domashchenko, D.V. (2010). Upravlenie riskami v usloviyakh finansovoi nestabilnosti [Managing risks in the context of financial uncertainty]. Moscow: INFRA-M.

Filippova, O.I. (2019). Osnovy ekonomiki i predprinimatelstva [Fundamentals of economics and entrepreneurship]. Workbook: Study aid. Moscow: Academia.

Foss, N.J. (2007). Scientific Progress in Strategic Management: The Case of the Resource-Based View. International Journal of Learning and Intellectual Capital (IJLIC), 4(1/2).

Gomola, A.I., Kirillov, V.E. (2019). Ekonomika [Economics]. Moscow: Academia.

Gubanov, R.S. (2014). Strakhovanie finansovykh riskov kak metod risk-menedzhmenta [Insurance of financial risks as a method of risk management]. Finansovaya analitika: problemy i resheniya [Financial Analytics: Science and Experience], 8, 31-35.

Kerimov, V.E. (2020). Upravlencheskii uchet [Management accounting]. Moscow: Dashkov i K.

Khrustalev, E. Iu., Slavianov, A. S. (2011). Problemy formirovaniya investitsionnoi strategii innovatsionno-orientirovannogo ekonomicheskogo rosta [Problems of investment strategy development for innovation-oriented economic growth]. Problemy prognozirovaniya [Studies on Russian Economic Development], 3(126), 19-30.

Kiseleva, I.A., Simonovich, N.E. (2014a). Ekonomicheskaya i sotsialno-psikhologicheskaya bezopasnost predpriyatiya [Economic and sociopsychologycal security of an enterprise]. Natsionalnye interesy: prioritety i bezopasnost [National Interests: Priorities and Security], 5, 30-34. 
Kiseleva, I.A., Simonovich, N.E. (2014b). Konkurentosposobnost predpriyatiya v usloviyakh globalizatsii obshchestva: vliyanie korporativnoi kultury [Competitiveness of an enterprise in the context of globalisation: the role of corporate culture]. Natsionalnye interesy: prioritety i bezopasnost [National Interests: Priorities and Security], 11, 39-44.

Kleiner, G.B. (2014). Riski malykh predpriyatii [Risks of small enterprise]. Rossiiskii ekonomicheskii zhurnal [Russian Economic Journal], 6, 85.

Kosov, M.E., Akhmadeev, R.G., Bykanova, O.A., Osipov, V.S., Ekimova, K.V., Frumina, S.V. (2016). Economic practicability substantiation of financial instrument choice. Journal of Applied Economic Sciences, 11(8), 1613-1623.

Makarenko, I.A. (2020). Teoriya ekonomicheskogo analiza [Theory of economic analysis]. Moscow: TetraSistems.

Morrow, J.L., Sirmon, D.G., Hitt, M.A., \& Holcomb, T.R. (2007). Creating Value in the Face of Declining Performance: Firm Strategies and Organizational Recovery. Strategic Management Journal, $8(3), 271-283$.

Porter, M. (2005). Konkurentnoe preimushchestvo: Kak dostich vysokogo rezultata i obespechit ego ustoichivost [The Competitive Advantage: Creating and Sustaining Superior Performance]. Moscow: Alpina Biznes Buks.

Shapkin, A.S. (2013). Ekonomicheskie i finansovye riski. Otsenka, upravlenie, portfel investitsii [Economic and financial risks. Assessment, management, investment portfolio]. Moscow: Dashkov i K.

Tereshchenko, O. N. (2019). Osnovy ekonomiki [Fundamentals of economics] Moscow: Academia.

Vakhitov, K.I. (2018). Economy: Study aid. Moscow: Academia.

Zhilkina, A. N. (2020) Upravlenie finansami. Finansovyi analiz predpriyatiya [Managing finance. Financial analysis of an enterprise]: Study aid. Moscow: INFRA-M. 